\title{
Mesiodistal and buccolingual crown size of deciduous teeth from a tooth bank in Brazil
}

\section{Dimensões mesiodistais e vestíbulo-linguais de coroas de dentes decíduos de um banco de dentes no Brasil}

\section{Taciana Emília de Almeida ANFE}

DDS, Ms - Department of Operative Dentistry - School of Dentistry - University of São Paulo Brazil.

\section{Yuri ARAKAKI}

DDS, PhD - Department of Operative Dentistry - School of Dentistry - University of São Paulo Brazil.

\section{Denise Moral NAKAMURA}

Undergraduate student - Department of Operative Dentistry - School of Dentistry - University of São Paulo - Brazil.

\section{Glauco Fioranelli VIEIRA}

DDS, PhD - Associate Professor - School of Dentistry - University of São Paulo - Brazil.

\begin{abstract}
Objective: The size of primary teeth in the current Brazilian population has not been studied yet; the aim of this in vitro study was to document the size and variation of deciduous teeth from a tooth bank in São Paulo, Brazil. Methods: A sample of 1,095 deciduous teeth was obtained from a tooth bank at the Dental School of the University of Sao Paulo. The measurements were made with a digital caliper. Only unworn, undamaged teeth were measured. Results: At mesiodistal diameter, maxillary central incisor showed the highest variation and the mandibular first molar the least. In buccolingual sizes, mandibular second molar was the tooth with the highest variability. Conclusion: This study provides a record of primary tooth sizes in Brazilian children. There was an evident variation of size of the primary teeth.
\end{abstract}

\section{KEYWORDS:}

Deciduous teeth; crown size; tooth bank.

\section{INTRODUCTION}

Deciduous teeth, forming from the first trimester until about 3 years of age, are a record of prenatal development. They also express genetic traits and may reflect environmental effects including maternal health, childhood disease and nutrition [1]. Deciduous teeth erupt until about 30 month of age and their replacement begins around 6 years of age, being completed by around 12 years of age $[2,3]$.
Mesiodistal crown diameter, also called tooth size, provides significant information on human evolution and biological problems as well as in forensic and clinical dentistry. Anthropologists use mesiodistal diameter to draw the evolution of tooth size. Tooth size provides a perception of connection between populations and environmental adaptation. The relationship between tooth size and dental crowding is reported by authors as being an important factor in clinical practice [4-9]. 
Information about morphologic characteristics of deciduous teeth can be useful for pediatric operative dentistry [10]. Tooth size is dependent upon race and sex [11]. The differences in tooth eruption, shape and size can reflect the process of evolution and provide a method of studying evolutionary mechanisms [12].

One aspect that demonstrates the importance of the studies on the size of deciduous tooth is that some dental anomalies have been associated with some diseases, such as Down syndrome [13], where tooth crown can be larger, especially on the mesiodistal aspect [14].

Studies on the primary dentition size are scarcer, but the mesiodistal diameter and the molar teeth have been mostly analyzed and reported; however, many of them either analyzed only mesiodistal diameters or only molars [9,12,13,15-18].

The size of primary teeth in the current Brazilian population has not been studied; therefore the aim of this in vitro study was to document the size and variation of deciduous teeth from a tooth bank in São Paulo, Brazil.

\section{Material and Methods}

A sample of 1,095 deciduous teeth was obtained from a tooth bank at the Dental School of the University of Sao Paulo. The evaluation was made in all deciduous tooth type, regardless of the side.

The measurements were made with a digital caliper (Mitutoyo, Japan) with $0.1 \mathrm{~mm}$ precision, according to Moorrees et al [19]. Only unworn, undamaged teeth were measured. All measurements were made by one author.

The criteria for each measurement were:

- Mesiodistal diameter: Two measurements were made; a) distance between the contact points and b) between cervical regions, measured with the caliper placed perpendicular to the occlusal surface (figure 1).

- Buccolingual diameter: the maximum width between the buccal and lingual surfaces perpendicular to the mesiodistal size (figure 1).

- Crown height: the distance from the cervical region to the occlusal surface (figure 2).

The data were tabulated in Microsoft Office Excel 2007. Mean, SD and coefficient of variation were calculated for each tooth type.

\section{Results}

For all measurements, SD and coefficient of variation were calculated. Mesiodistal and buccolingual dimensions are given in Table 1 and illustrated in Chart 1. Coefficient of variation is given in Table 2. Crown height dimensions are given in Table 3.

\section{Table 1 - Mesiodistal and buccolingual dimensions}

\begin{tabular}{c|c|c|c|c|c|c|c}
\hline \multirow{2}{*}{} & \multicolumn{2}{|c|}{$\begin{array}{c}\text { Mesiodistal diameterl between } \\
\text { contact points }\end{array}$} & \multicolumn{2}{c|}{$\begin{array}{c}\text { Mesiodistal diameter at } \\
\text { cervical region }\end{array}$} & \multicolumn{3}{c}{$\begin{array}{c}\text { Buccolingual } \\
\text { diameter }\end{array}$} \\
\hline & $n$ & Mean & SD & Mean & SD & Mean & SD \\
\hline $\mathrm{MXCl}$ & 53 & 6.465 & 0.812 & 5.2408 & 0.5796 & 5.1149 & 0.3700 \\
\hline $\mathrm{MXLI}$ & 181 & 4.9670 & 0.3900 & 3.5890 & 0.2779 & 4.5060 & 0.3863 \\
\hline $\mathrm{MXC}$ & 116 & 6.7909 & 0.4568 & 5.0855 & 0.3340 & 6.0164 & 0.4080 \\
\hline $\mathrm{MX}{ }^{\circ} \mathrm{M}$ & 195 & 6.9975 & 0.4830 & 6.070 & 1.318 & 8.6638 & 0.5829 \\
\hline $\mathrm{MX}{ }^{\circ} \mathrm{M}$ & 57 & 8.9256 & 0.5723 & 6.618 & 0.259 & 9.6230 & 0.4812 \\
\hline $\mathrm{MDCl}$ & 140 & 4.1430 & 0.2978 & 3.0895 & 0.2273 & 3.8694 & 0.3022 \\
\hline $\mathrm{MDLI}$ & 148 & 4.4600 & 0.2978 & 3.0895 & 0.2273 & 4.0905 & 0.3170 \\
\hline $\mathrm{MDC}$ & 116 & 6.7909 & 0.4568 & 5.0855 & 0.3340 & 6.0164 & 0.4080 \\
\hline $\mathrm{MD}{ }^{\circ} \mathrm{M}$ & 79 & 8.0906 & 0.5058 & 6.756 & 0.67 & 7.0500 & 0.4346 \\
\hline $\mathrm{MD}^{\circ}{ }^{\circ} \mathrm{M}$ & 10 & 10.018 & 0.449 & 7.8700 & 0.0849 & 8.671 & 0.451 \\
\hline
\end{tabular}

$\mathrm{MXCl}=$ maxillary central incisor; $\mathrm{MXLI}=$ maxillary lateral incisor; $\mathrm{MXC}=$ maxillary canine; $\mathrm{MX} 1 \mathrm{M}=$ maxillary first molar; $\mathrm{MX2M}=$ maxillary second molar; $\mathrm{MDCl}=$ mandibular central incisor; $\mathrm{MDLI}=$ mandibular lateral incisor; $\mathrm{MDC}=$ mandibular canine; $\mathrm{MD} 1 \mathrm{M}=$ mandibular first molar; $\mathrm{MD} 2 \mathrm{M}=$ mandibular second molar. 


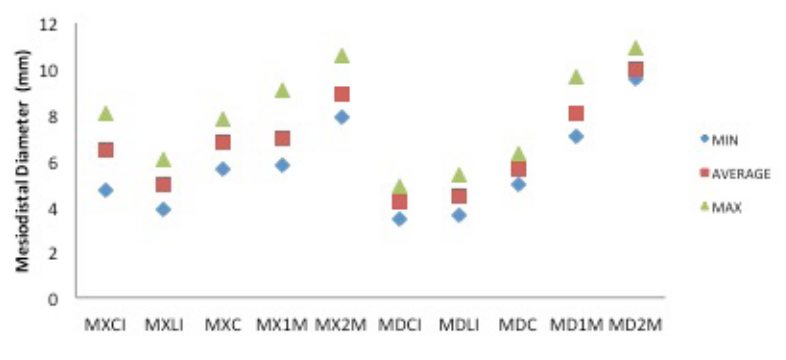

Chart 1 - Illustration of mesiodistal diameter measurements.

\section{Table 2 - Coefficient of variation}

\begin{tabular}{c|c|c}
\hline & Mesiodistal Diameter & Buccolingual Diameter \\
\hline $\mathrm{MXCl}$ & 0.01256 & 0.0007 \\
\hline $\mathrm{MXLI}$ & 0.00079 & 0.0009 \\
\hline $\mathrm{MXC}$ & 0.00067 & 0.0007 \\
\hline $\mathrm{MX1}{ }^{\circ} \mathrm{M}$ & 0.00069 & 0.0007 \\
\hline $\mathrm{MX2} 2^{\circ} \mathrm{M}$ & 0.00064 & 0.0005 \\
\hline $\mathrm{MDCl}$ & 0.00072 & 0.0008 \\
\hline $\mathrm{MDLI}$ & 0.00067 & 0.0008 \\
\hline $\mathrm{MDC}$ & 0.00067 & 0.0007 \\
\hline $\mathrm{MD1}{ }^{\circ} \mathrm{M}$ & 0.00063 & 0.0006 \\
\hline $\mathrm{MD2}{ }^{\circ} \mathrm{M}$ & 0.00448 & 0.0052 \\
\hline
\end{tabular}

\section{TABLE 3 - CROWN HEIGHT DIMENSIONS}

\begin{tabular}{c|c|c|c}
\hline \multicolumn{5}{|c}{ Crown height } \\
\hline & $n$ & Mean & SD \\
\hline $\mathrm{MXCl}$ & 53 & 6.2649 & 0.5320 \\
\hline $\mathrm{MXLI}$ & 181 & 6.1497 & 0.5787 \\
\hline $\mathrm{MXC}$ & 116 & 6.9049 & 0.5197 \\
\hline $\mathrm{MX1}{ }^{\circ} \mathrm{M}$ & 195 & 5.2214 & 0.4375 \\
\hline $\mathrm{MX2} 2^{\circ} \mathrm{M}$ & 57 & 5.3432 & 0.4597 \\
\hline $\mathrm{MDCl}$ & 140 & 5.5786 & 0.3847 \\
\hline $\mathrm{MDLI}$ & 148 & 5.7644 & 0.5056 \\
\hline $\mathrm{MDC}$ & 116 & 6.9049 & 0.5197 \\
\hline $\mathrm{MD}{ }^{\circ} \mathrm{M}$ & 79 & 6.0036 & 0.4673 \\
\hline $\mathrm{MD2}{ }^{\circ} \mathrm{M}$ & 10 & 5.501 & 0.477 \\
\hline
\end{tabular}

\section{Discussion}

Tooth measurement provides valuable data for anthropology and dentistry. These data are useful for restoring the crown of deciduous teeth and understanding the occlusion of deciduous dentition in pediatric dentistry [10]. Besides that, Bravo et al. [20] found that there is a relationship between the size of the deciduous second molar and the size of the permanent first molar. The authors believe that the size of deciduous teeth may be used as a predictive factor of tooth-jaw size disharmony. Thus, the size of deciduous teeth could be a predictive factor of possible crowding of the permanent dentition.

There are many studies of tooth size measurements $[4,9,12,17]$; however no study was found reporting deciduous tooth crown size of Brazilian children. In this study, the average of mesiodistal and buccolingual sizes and the heights of all primary teeth from a tooth bank were obtained. The method used in this study was based on the work of Moorrees [18]. This technique has been used in many studies $[4,12,20]$ and involves measurement of the greatest distance between the mesial and distal contact points using a digital caliper orientated parallel to the occlusal and vestibular surfaces.

When comparing the mesiodistal crown size obtained in the present study with those reported by other authors, no specific pattern was observed. The present values were numerically greater than, but close to the values obtained by Yuen [12] in Chinese children, where all deciduous teeth were also evaluated. Barbería et al. [17] evaluated the first and second deciduous molars in Spanish children. By comparing the values of these authors with those of our study, allow us to observe that the mandibular teeth are greater while the maxillary teeth are smaller than the ones of this present study. Bravo [20] evaluated only deciduous second molars in Spanish children and all the values were smaller than those obtained in this present study. Tsai [10] observed the characteristics of all deciduous teeth of children in Taiwan and their values are in agreement with those of this study.

We agree with all other authors that, apart from size, the mesiodistal size of mandibular molars are larger than those of the maxilla $[5,9,15,17,21,22]$.

In this study, the buccolingual widths were also observed and the values were compared with other studies. Axelsson and Kirveskar [23] evaluated mesiodistal and buccolingual sizes of all deciduous teeth. The comparison shows that in both reports the values are coincident with those of this study. Liversidge and Molleson [1] also measured the mesiodistal and buccolingual sizes. The mesiodistal width presented values close to those of our study; however the buccolingual measurements exhibited smaller sizes than those of this study.

The authors found only one study that measured 
the crown height. Barbería et al. [17] showed crown height values of deciduous first and second molars smaller than we found in our study. It was not possible to compare the other teeth values because of lack of data in the literature.

Variability is an important component of the human dental structure [24]. The results show that, in mesiodistal diameter, maxillary central incisor was the tooth with the highest variability, followed by mandibular second molar. The tooth with the lowest variability was mandibular first molar. In buccolingual diameter, mandibular second molar was the tooth with the highest variability.

\section{Conclusions}

Information about tooth size measurements can be important for anthropological and forensic significance and for clinical practice. This study provides a record of deciduous teeth size in Brazilian children, since the authors have measured all deciduous teeth. There was an evident variation of size, where in mesiodistal diameter maxillary central incisor showed the highest variation and first mandibular molar the least. In buccolingual sizes, mandibular second molar was the tooth with the highest variability.

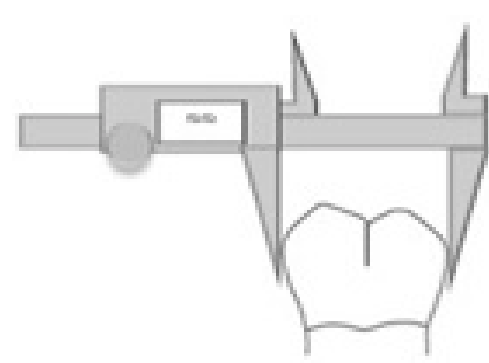

a)

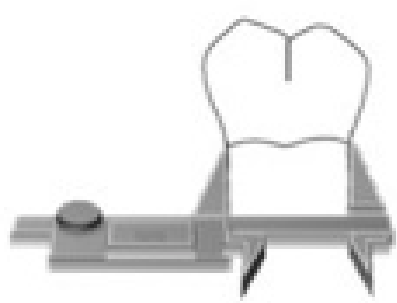

b)

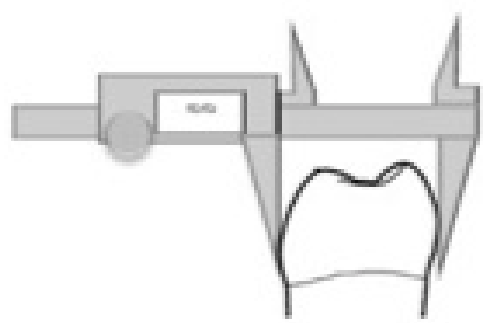

c)

Figure 1 - Measurement of: a) mesiodistal diameter between contact points; b) mesiodistal diameter at cervical region; c) buccolingual diameter.

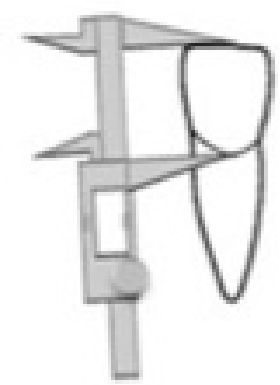

Figure 2 - Measurement of crown height.

\begin{abstract}
Resumo
Objetivo: O tamanho dos dentes decíduos na população brasileira atual ainda não foi estudado, o objetivo deste estudo in vitro foi documentar o tamanho e a variação de dentes decíduos de um banco de dentes, em São Paulo, Brasil. Métodos: Uma amostra de 1.095 dentes decíduos foi obtida a partir de um banco de dentes da Faculdade de Odontologia da Universidade de São Paulo. As medições foram feitas com um paquímetro digital. Apenas dentes não desgastados e não danificados foram medidos. Resultados: Em relação ao diâmetro mesiodistal, o incisivo central superior apresentou a maior variação e primeiro molar inferior a mínima. Em relação aos tamanhos vestíbulo-linguais, o segundo molar foi o dente com a maior variabilidade. Conclusão: Este estudo forneceu um registro de tamanhos dos dentes decíduos de crianças brasileiras. Houve uma variação evidente de tamanho dos dentes decíduos.
\end{abstract}

\title{
PalaVRas-chave
}

Dentes decíduos; dimensão de coroa; banco de dentes. 


\section{REFERÊNCIAS}

1. Liversidge HM, Molleson TI. Deciduous tooth size and morphogenetic fields in children from Christ Church, Spitalfields. Arch Oral Biol. 1999;44(1):7-13.

2. Hagg U, Taranger J. Dental development, dental age and tooth counts. Angle Orthod. 1985;55(2):93-107.

3. Maki K, Morimoto A, Nishioka T, Kimura M, Braham RL. The impact of race on tooth formation. ASDC J Dent Child. 1999;66(5):353-6, 294-5.

4. Hattab FN, al-Khateeb S, Sultan I. Mesiodistal crown diameters of permanent teeth in Jordanians. Arch Oral Biol. 1996;41(7):641-5.

5. Margetts B, Brown T. Crown diameters of the deciduous teeth in Australian Aboriginals. Am J Phys Anthropol. 1978;48(4):493-502.

6. Radnzic D. Dental crowding and its relationship to mesiodistal crown diameters and arch dimensions. Am J Orthod Dentofacial Orthop. 1988;94(1):50-6.

7. Bermudez de Castro JM, Nicolas ME. Posterior dental size reduction in hominids: the Atapuerca evidence. Am J Phys Anthropol. 1995;96(4):335-56.

8. Tsai HH. Dental crowding in primary dentition and its relationship to arch and crown dimensions. J Dent Child. 2003;70(2):164-9.

9. Warren JJ, Bishara SE, Yonezu T. Tooth size-arch length relationships in the deciduous dentition: a comparison between contemporary and historical samples. Am J Orthod Dentofacial Orthop. 2003;123(6):614-9.

10. Tsai HH. Morphological characteristics of the deciduous teeth. J Clin Pediatr Dent. 2001;25(2):95-101.

11. Moorrees CF, Reed RB. Correlations among crown diameters of human teeth. Arch Oral Biol. 1964;9:685-97.

12. Yuen KK, So LL, Tang EL, Mesiodistal crown diameters of the primary and permanent teeth in southern Chinese--a longitudinal study. Eur J Orthod. 1997;19(6):721-31.

13. Peretz B, Katzenel V, Shapira J. Morphometric variables of the primary second molar in children with Down syndrome. J Clin Pediatr Dent. 1999;23(4):333-6.

14. Barden HS, Mesiodistal crown size dimensions of permanent and deciduous teeth in Down syndrome. Hum Biol. 1980;52(2):247-53.

15. Anderson AA. Dentition and occlusion development in African American children: mesiodistal crown diameters and tooth-size ratios of primary teeth. Pediatr Dent. 2005;27(2):121-8.

16. Harris EF, Lease LR. Mesiodistal tooth crown dimensions of the primary dentition: a worldwide survey. Am J Phys Anthropol. 2005;128(3):593-607.

17. Barbería E, Suárez MC, Villalón G, Maroto M, GarcíaGodoy F. Standards for mesiodistal and buccolingual crown size and height of primary molars in a sample of Spanish children. Eur J Paediatr Dent. 2009;10(4):169-75.

18. Jensen E, Kai-Jen Yen P, Moorrees CF, Thomsen SO. Mesiodistal crown diameters of the deciduous and permanent teeth in individuals. J Dent Res, 1957;36(1):39-47.

19. Ahmad I. Geometric considerations in anterior dental aesthetics: restorative principles. Pract Periodontics Aesthet Dent. 1998;10(7):813-22; quiz 824.

20. Bravo N, Facal M, Maroto M, Barbería E. Relationship between mesiodistal crown diameters of permanent first molars and deciduous second molars. Eur J Paediatr Dent. 2010;11(3):115-21.
21. Kondo S, Townsend GC. Sexual dimorphism in crown units of mandibular deciduous and permanent molars in Australian Aborigines. Homo. 2004;55(1-2):53-64.

22. Lysell L, Myrberg N. Mesiodistal tooth size in the deciduous and permanent dentitions. Eur J Orthod. 1982;4(2):113-22.

23. Axelsson G, Kirveskari P. Crown size of deciduous teeth in Icelanders. Acta Odontol Scand. 1984;42(6):339-43.

24. Doris JM, Bernard BW, Kuftinec MM, Stom D. A biometric study of tooth size and dental crowding. Am J Orthod. 1981;79(3):326-36.

Received: 14/08/2012

Accepted: 14/08/2012

Corresponding author: Taciana Emília de Almeida Anfe taciana@usp.br

Avenida Professor Lineu Prestes, 2227

São Paulo - SP CEP: 05508-000

Brazil 